John Carroll University

Carroll Collected

Biology

$9-2008$

\title{
Shrub-interspace dynamics alter relationships between microbial community composition and belowground ecosystem characteristics
}

Rebecca E. Drenovsky

John Carroll University, rdrenovsky@jcu.edu

Z. T. Aanderud

University of California, Davis

M. I. Shuldman

University of California, Davis

J.H. Richards

University of California, Davis

Follow this and additional works at: http://collected.jcu.edu/biol-facpub

Part of the Biology Commons, and the Plant Biology Commons

\section{Recommended Citation}

Drenovsky, Rebecca E.; Aanderud, Z. T.; Shuldman, M. I.; and Richards, J. H., "Shrub-interspace dynamics alter relationships between microbial community composition and belowground ecosystem characteristics" (2008). Biology. 24.

http://collected.jcu.edu/biol-facpub/24 


\title{
Shrub-interspace dynamics alter relationships between microbial community composition and belowground ecosystem characteristics
}

\author{
Zachary T. Aanderud ${ }^{\text {a,d, } *}$, Michal I. Shuldman ${ }^{\text {a,b }}$, Rebecca E. Drenovsky ${ }^{c}$, James H. Richards ${ }^{\text {a }}$ \\ ${ }^{a}$ Land, Air, and Water Resources Department, University of California, Davis, CA 95616, USA \\ ${ }^{\mathrm{b}}$ Department of Integrative Biology, University of California, Berkeley, CA 94720, USA \\ ${ }^{\mathrm{c}}$ Biology Department, John Carroll University, University Heights, OH 44118, USA \\ ${ }^{\mathrm{d}}$ W. K. Kellogg Biological Station, Michigan State University, Hickory Corners, MI 49060, USA
}

Keywords:

Artemisia tridentata

Cold deserts

Interspaces

Microbial community composition

Phospholipid fatty acid analysis

Sarcobatus vermiculatus

Tetradymia tetrameres

\begin{abstract}
A B S T R A C T
In desert ecosystems, belowground characteristics are influenced chiefly by the formation and persistence of "shrub-islands of fertility" in contrast to barren plant interspaces. If soil microbial communities are exclusively compared between these two biogeochemically distinct soil types, the impact of characteristics altered by shrub species, especially soil $\mathrm{C}$ and $\mathrm{N}$, are likely to be overemphasized and overshadow the role of other characteristics in structuring microbial composition. To determine how belowground characteristics influence microbial community composition, and if the relative importance of these characteristics shifts across the landscape (i.e., between and within shrub and interspace soils), changes in microbial communities across a 3000-year cold desert chronosequence were related to 27 belowground characteristics in surface and subsurface soils. When shrub and interspace communities in surface and subsurface soils were combined across the entire chronosequence, communities differed and were primarily influenced by soil $\mathrm{C}, \mathrm{NO}_{3}^{-}$concentrations, bulk density, $\mathrm{pH}$, and root presence. Within shrub soils, microbial communities were shrub species-specific, especially in surface soils, highlighting differences in soil characteristics created by specific shrub species and/or similarity in stresses structuring shrub species and microbial communities alike. Microbial communities in shrub soils were not influenced by soil C, but by $\mathrm{NO}_{3}^{-}$and $\mathrm{NH}_{4}^{+}$concentrations, $\mathrm{pH}$, and silt in surface soils; and $\mathrm{Cl}, \mathrm{P}$, soil $\mathrm{N}$, and $\mathrm{NO}_{3}^{-}$concentrations in subsurface soils. Interspace soil communities were distinct across the chronosequence at both depths and were strongly influenced by dune development. Interspace communities were primarily associated with soil stresses (i.e., high $\mathrm{B}$ and $\mathrm{Cl}$ concentrations), which decreased with dune development. The distribution of Gram-positive bacteria, Actinobacteria, and fungi highlighted community differences between and within shrub and interspace soils, while Gram-negative bacteria were common in all soils across the chronosequence. Of the 27 belowground characteristics investigated, 13 separated shrub from interspace communities, and of those, only five emerged as factors influencing community composition within shrub and interspace soils. As dunes develop across this cold desert chronosequence, microbial community composition was not regulated primarily by soil C, but by $\mathrm{N}$ and $\mathrm{P}$ availability and soil stresses in shrub soils, and exclusively by soil stresses in interspace soils.
\end{abstract}

\section{Introduction}

Microbial community composition mediates decomposition processes, regulates nutrient cycling, and influences soil functional diversity. In many terrestrial ecosystems, microbial communities are regulated primarily by quantity and quality of available organic $C$ sources (Bossio and Scow, 1998; Griffiths et al., 1999; Fierer et al., 2003b) and, secondarily, by physiochemical stresses (e.g., pH, EC, salinity, and heavy metals) and soil moisture (Pankhurst et al., 2001; Wilkinson et al., 2002; Fierer et al., 2003a; Griffiths et al., 2003; Cordova-Kreylos et al., 2006). Despite arid and semi-arid environments comprising 30-40\% of the Earth's terrestrial biomes (Dregne, 1991), it remains unknown how belowground characteristics influence microbial community composition in these ecosystems or if these relationships shift across the landscape during ecosystem development.

In desert ecosystems, belowground characteristics are influenced chiefly by the formation and persistence of "shrub-islands of fertility" in contrast to barren plant interspaces (Charley and West, 1975). Across these landscapes, soils beneath shrubs are enriched in soil $\mathrm{C}$ and other essential elements (e.g., N, P, and Ca) due to litter 
and root inputs, root translocation of elements from interspace soils, and shrub canopies' trapping of aeolian material (Schlesinger et al., 1996; Schlesinger and Pilmanis, 1998). Further, as shrubislands persist, biogenic dunes are formed and soil physiochemical properties are altered due to soil formation processes and leaching of chemical constituents, via snow melt and precipitation (Vasek and Lund, 1980; Toft and Elliott-Fisk, 2002). In the few studies assessing microbial community composition between shrub and interspace soils, the importance of shrub-islands in structuring communities was evident (Vollmer et al., 1977; Collins and Cavigelli, 2003; Ewing et al., 2007). Relative to interspace soils, shrub soils have higher total soil $\mathrm{C}$ and $\mathrm{N}$, support more microbial biomass, and are associated with higher $\mathrm{C}$ and $\mathrm{N}$ mineralization rates (Gallardo and Schlesinger, 1992; Schaeffer et al., 2003; Schaeffer and Evans, 2005; Ewing et al., 2007). By exclusively comparing these two inherently distinct soils that differ so much in their biogeochemistry, the impact of $\mathrm{C}$ and $\mathrm{N}$ availability on community composition is likely to be overemphasized and overshadow the role of other belowground characteristics in structuring desert microbial composition. If microbial communities are evaluated within shrub and interspace soils as they develop, other belowground characteristics, which influence microbial community composition, are likely to be revealed.

During dune development, soil stresses, moisture variability, nutrient availability, and organic $\mathrm{C}$ and $\mathrm{N}$ vary both within shrub and interspace soils (Reynolds et al., 1999; Donovan and Richards, 2000; Toft and Elliott-Fisk, 2002; Gillespie and Loik, 2004; Drenovsky and Richards, 2005) and potentially influencing microbial community composition. For example, as dunes develop and the shrub species diversity increases, different shrub species, with their specific leaf chemistry and nutrient and water demands, may create unique soil environments that select for particular microorganisms. Also, the severity of soil stresses (e.g., alkalinity and salinity) vary between young and old dunes, creating soil environments that may select for microorganisms that can exist and thrive under specific soil conditions.

To determine how belowground characteristics influence microbial community composition, and if the relative importance of these characteristics shifts across the landscape (i.e., between and within shrub and interspace soils), changes in microbial communities composition across a 3000-year cold desert chronosequence were related to 27 belowground characteristics in surface $(0-10 \mathrm{~cm})$ and subsurface soils $(30-40 \mathrm{~cm})$. Community composition using phospholipid fatty acid (PLFA) analysis was evaluated at these two depths due to the reoccurring significance of depth in structuring microbial communities in other ecosystems (Blume et al., 2002; Fierer et al., 2003b) and because of the high variability in desert belowground characteristics between surface and subsurface soils (Charley and West, 1975; Schlesinger and Pilmanis, 1998). We hypothesize that microbial communities in shrub and interspace soils will differ and be associated primarily with $\mathrm{C}$ and $\mathrm{N}$ distribution. However, once differences in $\mathrm{C}$ and $\mathrm{N}$ are removed, microbial community composition within shrub soils will be specific to shrub species, while microbial communities in interspace soils will be similar, regardless of placement along the chronosequence. Further, both shrub and interspace communities will be associated with characteristics other than those relating to $\mathrm{C}$ and $\mathrm{N}$. Lastly, we hypothesize that across the chronosequence the influence of soil stresses on microbial community composition will decline as soil stresses are alleviated during dune development.

\section{Materials and methods}

\subsection{Site description and sampling}

Due to late Holocene fluctuations in lake level ( $40 \mathrm{~m}$ over the last 3800 years) and recent drawdown for agricultural and urban uses, a series of shoreline dunes have formed across the Mono Basin Ecosystem Research Site (MBERS, 38 ${ }^{\circ} 5^{\prime} \mathrm{N}, 118^{\circ} 58^{\prime} \mathrm{W}, 1970 \pm 20 \mathrm{~m}$ elevation a.s.l.), in Mono Valley northeast of Mono Lake, CA. The MBERS chronosequence consists of four dunes at different stages of development, and their ages at the time of sampling in 2004 were: Shadow Dunes (Shadow) $=47$ years, Transverse Dunes (Transverse $)=85$ years, Diverse Dunes (Diverse) $\approx 300$ years, and Oldgrowth Dunes (Old-growth) $\approx 1800-3000$ years since exposure by lake recession. Dating for the dunes was based on historical, sedimentary, and geomorphic evidence combined with tephrostratigraphy results for four tephra units of a known age, and $25{ }^{14} \mathrm{C}$ radiocarbon dates of vegetation remains (Stine, 1990). Shrub soils at Shadow and Transverse were dominated by a single shrub species, Sarcobatus vermiculatus (Hook.) Torrey (Chenopodiaceae), and represent early stages of dune complex development. Shrub soils at Old-growth were dominated by many shrub species, the most important of which were S. vermiculatus and Artemisia tridentata Nutt. ssp. tridentata (Asteraceae), and represent a stable dune complex. Diverse shrub soils were dominated by $S$. vermiculatus, Tetradymia tetrameres (S.F. Blake) Strother (Asteraceae) and Chrysothamnus nauseosus (Pallas) Britton ssp. consimilis (E. Greene) H.M. Hall and Clements (Asteraceae), and represent a transition developmental stage between the two younger dunes and Oldgrowth. For more details of plant community composition and succession on the dunes see Fort and Richards (1998), Donovan and Richards (2000), Toft and Elliott-Fisk (2002).

Across MBERS, eight locations were randomly selected at each dune with each location containing shrub species of interest and an interspace at least $1 \mathrm{~m}$ away from all target (or experimental) plants. Shrubs and interspaces were selected randomly using GPS coordinates that fell within each of the four dune complexes. In July 2004 , samples were collected from surface $(0-10 \mathrm{~cm})$ and subsurface soils $(30-40 \mathrm{~cm})$ from shrub soils of $S$. vermiculatus and interspaces at Shadow and Transverse; from shrub soils of $S$. vermiculatus, T. tetrameres and interspaces at Diverse; and from shrub soils of $S$. vermiculatus, A. tridentata and interspaces at Old-growth. All samples for each depth consisted of three composite subsamples removed with a soil corer $(10 \mathrm{~cm}$ diameter $\times 10 \mathrm{~cm}$ deep). Shrub soil samples were taken $30 \mathrm{~cm}$ inward from the canopy edge. From these bulked sub-samples, PLFA analyses and belowground characteristics were quantified. Samples were replicated within four dunes $\times$ two or three shrub soils and interspace locations $\times$ two depths $\times$ five replicates $(n=100)$. All soil samples were cooled immediately after sampling and stored prior to transport at approximately $3{ }^{\circ} \mathrm{C}$. We focused on microorganisms residing within the soil matrix and not surface biological soil crusts due to biological crusts being rare across MBERS.

\subsection{PLFA analysis and community characteristics}

Soil microbial community composition was assessed using PLFA analysis on five randomly selected samples from each dune, location, and depth combination using a modified Bligh and Dyer (1959) procedure as described in full by Bossio and Scow (1998). Briefly, fatty acids were extracted from moist soil ( $8 \mathrm{~g}$ dry soil) using a single-phase solvent (chloroform-methanol-phosphate buffer), polar and non-polar lipids were separated using solid phase extraction columns, $0.50 \mathrm{~g}$ Si (Supelco, Inc., Bellefonte, PA), and fatty acids were analyzed using a Hewlett Packard 6890 Gas Chromatograph with a 25-m Ultra 2 (5\%-phenyl)-methylpolysiloxane column (Agilent Technologies, Santa Clara, CA) and $\mathrm{H}_{2}$ as a carrier gas. A $2 \mu \mathrm{l}$ injection of each sample was analyzed at an initial temperature of $170^{\circ} \mathrm{C}$, ramped to $260^{\circ} \mathrm{C}$ at $2{ }^{\circ} \mathrm{C} \mathrm{min}-1$. The resulting peaks were identified according to retention times compared to bacterial fatty acid standards and MIDI peak identification software (MIDI, Inc., Newark, DE). Peak identity was previously 
verified by comparing mass spectrometry EI spectra to spectra from standards, and confirming molecular weights with chemical ionization spectra using a Varian 3400 gas chromatograph interfaced with a Finnigan ITD 806 mass spectrometer. Quantification was performed with 19:0 as an internal standard. Soils used for PLFA analysis were frozen $\left(-20^{\circ} \mathrm{C}\right)$ within $48 \mathrm{~h}$ of sampling.

PLFA analysis can be used to determine microbial community composition, as well as the relative abundances of specific microbial groups (e.g., Actinobacteria, Gram-positive bacteria, Gramnegative bacteria, and fungi). The nomenclature used to distinguish fatty acids describes the total number of C atoms (17:1 $\omega 9 \mathrm{c})$ attended by the number of double bonds $(17: 1 \omega 9 \mathrm{c})$ with $(\omega)$ the position of double bonds from the methyl end of the molecule identified as

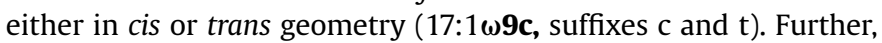
prefixes a, i, and cy refer to anteiso- and iso-branching in the molecule and cyclopropane fatty acids. $10 \mathrm{Me}$ indicates the presence of methyl group on the tenth $C$ from the carboxyl end of the molecule. The presence and position of a hydroxyl $(\mathrm{OH})$ group is indicated following the nomenclature for the double bond (16:012OH). The following fatty acids were used to identify groups of microorganisms: (1) Actinobacteria-10Me16:0, 10Me17:0, and 10Me18:0 (Zelles et al., 1994; White et al., 1996; Fierer et al., 2003b); (2) Gram-positive bacteria-i14:0, a15:0, i15:0, i16:0, i17:0, and a17:0 (Kourtev et al., 2003; Fierer et al., 2003b); (3) Gram-

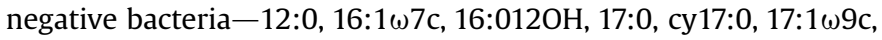

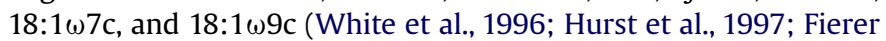

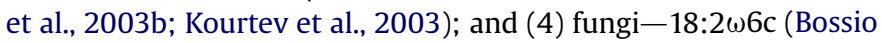
and Scow, 1998; Fierer et al., 2003b). These groups are based on published identification of individual PLFA from pure cultures and represent a conservative estimate of each group using a total of 18 of 43 fatty acids in the dataset.

Fatty acids were expressed as nanomoles per gram dry weight of soil. Total fatty acids used for shrub and interspace comparisons $=43$ and for shrub surface $=42$, shrub subsurface $=31$, interspaces surface $=33$, and interspace subsurface $=20$. Fatty acids that were rare (appeared in less than $4 \%$ of the 100 samples) and/or close to the detection limit were removed to correct for the disproportionate weight given to these samples in multivariate analyses.

\subsection{Belowground ecosystem characteristics}

The 27 parameters describing belowground ecosystem properties were grouped into four categories: (1) C and $\mathrm{N}$ availability-soil $\mathrm{C}$ and $\mathrm{N}$, litter $\mathrm{C}$ and $\mathrm{N}$, total mass of live and dead roots, and inorganic $\mathrm{NH}_{4}^{+}$and $\mathrm{NO}_{3}^{-}$; (2) macro and micronutrients-soil concentrations of $\mathrm{P}, \mathrm{K}, \mathrm{S}, \mathrm{Ca}, \mathrm{Mg}, \mathrm{Mn}, \mathrm{Fe}$, and $\mathrm{Zn}$; (3) physical properties-bulk density, gravimetric soil moisture at time of harvest, \% clay, \% silt, and \% sand; and (4) potential stresses- $\mathrm{pH}$, electrical conductivity, soil concentrations of $\mathrm{B}, \mathrm{Cl}$, and $\mathrm{Na}$, sodium adsorption ratio, and carbonate alkalinity. Parameters in the soil stress category were based on existing stresses known to negatively impact microbial community composition, diversity, and/or biomass (Pathak and Rao, 1998; Pankhurst et al., 2001; Acosta-Martinez et al., 2003) and soil physiochemical characteristics that have caused deleterious effects on plant species at MBERS (Donovan et al., 1997; Donovan and Richards, 2000; Toft and Elliott-Fisk, 2002).

\subsection{1. $C$ and $N$ availability}

Soils were sieved to $2 \mathrm{~mm}$ and litter and roots retained on the sieve were separated by hand. All soil $\mathrm{C}$ and $\mathrm{N}$ pools, except inorganic $\mathrm{N}$ concentrations, were dried, weighed, ground, and analyzed for \% $\mathrm{C}$ and \% via dry combustion gas chromatographyisotope ratio mass spectrometry on a Europa Scientific 20-20 (Crewe, UK) at the UC Davis Stable Isotope Facility. Total soil organic $C$ and soil inorganic $C$ (SIC) were measured by difference from nonfumigated and $\mathrm{HCl}$ fumigated subsamples following a modified protocol outlined by Harris et al. (2001). Due to the large amount of contamination by SIC, soil samples were fumigated for $48 \mathrm{~h}$ and dried for $2 \mathrm{~h}$ at $70^{\circ} \mathrm{C}$. To remove any SIC contamination from the litter and roots, both of these pools were fumigated for $24 \mathrm{~h}$ and dried for $2 \mathrm{~h}$ at $70^{\circ} \mathrm{C}$ prior to analysis for \%C and \%N. Soil $\mathrm{NH}_{4}^{+}$and $\mathrm{NO}_{3}^{-}$was extracted with $2 \mathrm{M} \mathrm{KCl}$ and measured on a Carlson analyzer (Carlson, 1978).

\subsubsection{Macro- and micronutrients and soil stresses}

Concentrations (mM) of soil stresses $\mathrm{B}, \mathrm{Cl}, \mathrm{Na}$, and $\mathrm{S}$, and nutrients P, S, Ca, Mg, Mn, Fe, and Zn were determined from saturated paste extractions that were equilibrated for $24 \mathrm{~h}$, filtered through a $0.45 \mu \mathrm{m}$ nylon filter, and measured by inductively coupledplasma atomic-emission spectrophotometry (ICP-AES, Thermo Jarrell Ash Corp., Franklin, MA). From these values, sodium adsorption ratios were calculated in $\mathrm{mmol}^{-1}$ as follows: $\mathrm{SAR}=\left[\mathrm{Na}^{+}\right] / \sqrt{ }\left(0.5\left(\left[\mathrm{Ca}^{2+}\right]+\left[\mathrm{Mg}^{2+}\right]\right)\right)$. Other soil stresses were evaluated as follows: $\mathrm{pH}$ in $1: 1$ soil to water extracts that were allowed to equilibrate for $1 \mathrm{~h}$; electrical conductivity $\left(E C_{e}\right)$ from saturated paste extracts treated similarly as soil nutrient determinations; and alkalinity $\left(\mathrm{HCO}_{3}^{-}+2 \mathrm{CO}_{3}^{2-}+\mathrm{OH}^{-}-\mathrm{H}^{+}\right)$by measuring total carbonate in soil saturated paste extracts on a Phoenix 8000 total organic C analyzer (Teledyne Tekmar, $\mathrm{OH}$ ) and calculating the relative contributions of carbonate species using the Henderson-Hasslebach equation.

\subsubsection{Physical properties}

Gravimetric soil moisture at harvest was assessed by drying soil at $105{ }^{\circ} \mathrm{C}$ for $48 \mathrm{~h}$. Particle size analysis for \% sand, silt, and clay was completed on soil samples sieved to $2 \mathrm{~mm}$ and analyzed by laser diffraction on a Coulter LS-230 particle size analyzer (Beckman Coulter Inc. Miami, FL, Eshel et al., 2004).

\subsection{Statistical analysis}

Variation in microbial community composition was assessed using correspondence analysis (CA), an indirect, unconstrained ordination method (terBraak and Šmilauer, 1998; Steenwerth et al., 2002; Cordova-Kreylos et al., 2006). CA was performed on all samples and then on individual shrub and interspace soils by depth. Differences $(P \leq 0.05)$ among microbial communities were determined by comparing the first axis ordination scores using analysis of variance (ANOVA). Also, ANOVA was used to determine differences $(P \leq 0.05)$ among community characteristics (i.e., biomass, PLFA number, and groups of microorganisms) within shrub and interspace soils by depth. ANOVA assumptions were evaluated using the Shapiro-Wilk test for normality and Levene's test for homogeneity of variance. Since all pair-wise combinations were of interest, means were separated using Tukey's student range test. All univariate analyses were conducted using SAS/STAT (SAS, 2001).

Canonical correspondence analysis (CCA), a direct, constrained ordination method, was used to test specific hypotheses about the relationships between ecosystem characteristics and microbial community composition (terBraak and Šmilauer, 1998; CordovaKreylos et al., 2006). The significance of environmental variables present in the ordination was determined by Monte Carlo permutation tests (terBraak and Šmilauer, 1998). CCA was performed on all samples and then on shrub and interspace soils by depth (i.e., shrub surface, shrub subsurface, interspace surface, interspace subsurface) across the chronosequence. The number of microbial communities sampled in individual shrub and interspace by depth locations did not allow for all of the 27 ecosystem characteristics to be simultaneously analyzed in a CCA. Therefore, to equally weigh all belowground characteristics, CCA were first performed for each location with the four ecosystem characteristics groups separately (i.e., $\mathrm{C}$ and $\mathrm{N}$ availability, macro and micronutrients, physical 
properties, and stresses). Following these analyses, the three variables with the highest $F$ value and lowest $P$ value within each group (this always included all significant variables, $P \leq 0.05$ ) were included in a composite CCA for each shrub and interspace soils by depth combination. All ordination analyses were performed with CANOCO 5.1 (Microcomputer Power, NY).

\section{Results}

\subsection{Microbial communities between shrub and interspace soils}

Shrub and interspace communities in surface and subsurface soils were distinct from one another irrespective of combining all microbial communities across the 3000 year chronosequence into one of these four locations (Fig. 1). The first two axes of the CA explained $46 \%$ of the total variation in microbial communities, with communities separating by soil depth on axis 1 (33.6\%) and by shrub versus interspace on axis 2 (12.6\%). All distinctions between microbial communities from all CA either between or within shrub and interspace soils were based solely on the first axis. By depth, shrub relative to interspace soils had a higher mole \% of Grampositive bacteria and fungi (Fig. 2C). Within shrub soils, subsurface had a higher mole \% of Actinobacteria relative to the surface. There was at least seven-times the biomass and three times the diversity (using number of fatty acids as a proxy for diversity, CordovaKreylos et al., 2006) in shrub surface soils relative to any another soil type (Fig. 2A,B). Due to the different parent material (volcanic blast) and anoxic conditions of subsurface soils at Shadow, this location was excluded from shrub versus interspace comparisons and individual analyses associated with interspace soils.

\subsection{Belowground characteristics and shrub and interspace communities}

The separation between shrub and interspace communities in surface and subsurface soils was influenced predominantly by bulk density, $\mathrm{NO}_{3}^{-}$concentrations, $\mathrm{pH}$, root presence, and soil $\mathrm{C}$, and, to a lesser extent, by gravimetric water content at time of harvest (i.e.,

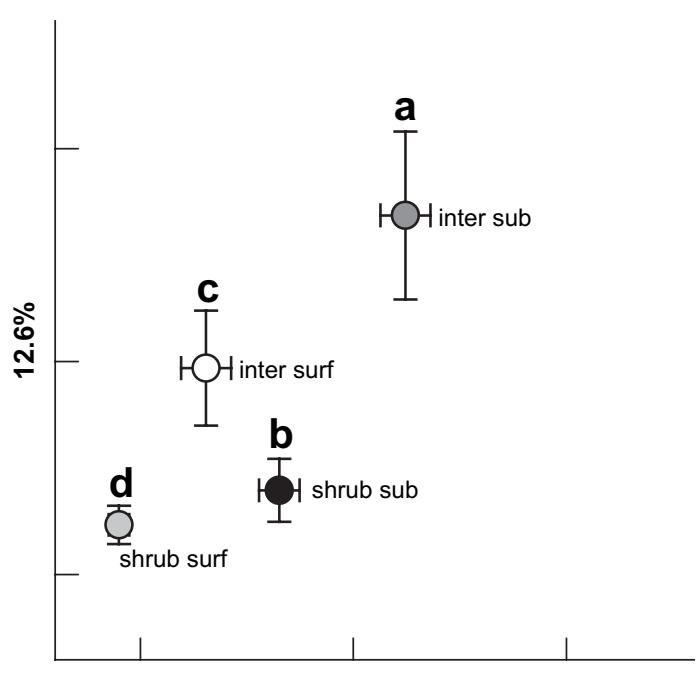

$33.6 \%$

Fig. 1. Correspondence analysis $(\mathrm{CA})$ results of microbial communities from shrub and interspace (inter) soils across MBERS. Communities are from surface (surf, 0-10 cm) and subsurface soils (sub, $30-40 \mathrm{~cm})$. Values are means $(n=12-15)$ with standard errors of the means of axis 1 ( $x$ axis) and 2 scores ( $y$ axis). Different letters indicate significant differences $(P \leq 0.05)$ between communities along axis 1 . For all CA plots, values on the $x$ and $y$ axes represent the percent variation explained by axis 1 and 2 respectively.
July), Ca concentrations, and soil texture (Fig. 3, Table 1). Communities separated on axis 1 mainly by the presence of roots, and on axis 2 by bulk density, $\mathrm{NO}_{3}^{-}$concentrations, $\mathrm{pH}$, and soil $\mathrm{C}$. Interspace soil communities at both depths were associated with low soil $\mathrm{C}$ and $\mathrm{N}$, and higher bulk densities, while shrub soil communities at $40 \mathrm{~cm}$ were associated with the presence of roots and higher gravimetric water content (Fig. 3, Table 1). Interspace soils consistently had higher bulk densities and lower values of soil C than all shrub soils regardless of depth. All of the characteristics represented in the CCA had $P$ values $=0.002$. Other characteristics that were also significant included $\mathrm{NH}_{4}^{+}, \mathrm{B}, \mathrm{Mg}$, and Mn concentrations with $P$ values $=0.004,0.006,0.02$, and 0.01 respectively (data not shown). For the values of all significant belowground characteristics see Table 1 . The table does not include Mg and Mn concentrations, which had a grand mean $(n=94$, followed by one standard error) across the entire chronosequence of $0.24 \pm 0.03 \mathrm{mmol} \mathrm{L}^{-1}$ and $1.12 \pm 0.21 \mu \mathrm{mol} \mathrm{L}^{-1}$ respectively.

\subsection{Microbial communities within shrub soils}

Within shrub soils, microbial communities were separated by shrub species and the different stages of dune development (Fig. 4A,B). Communities at the surface separated by shrub species along axis $1(30.8 \%)$ with all S. vermiculatus communities similar to each other, regardless of location across the chronosequence. Microbial communities associated with A. tridentata and T. tetrameres were different, but similar to communities associated with $S$. vermiculatus soils at their respective position along the chronosequence (e.g., microbial communities at Diverse were the same regardless of whether from $T$. tetrameres or $S$. vermiculatus soils). Based on axis 1, communities in shrub subsurface soils beneath $S$. vermiculatus at the youngest dunes were different from each other and from all other communities. In contrast, communities associated with $S$. vermiculatus soils at the two older dunes, Diverse and Old-growth, were not different from each other or the microbial community associated with T. tetrameres. Microbial communities in A. tridentata soils were similar to $T$. tetrameres but differed from all communities associated with S. vermiculatus soils. Microbial communities in subsurface soils roughly separated by dune age and development on axis 1 (31.2\%) and by shrub species on axis 2 (16.6\%).

The patterns described by the CA of shrub soil communities were reflected in the communities' biomass, diversity, and distribution of the four microbial groups in subsurface soils and to a lesser extent in surface soils (Fig. 4A,B, Table 2). In subsurface soils, lower diversity and relatively lower mole $\%$ to absence of Gram-positive bacteria, fungi, and Actinobacteria highlighted the differences between the Shadow and Transverse $S$. vermiculatus microbial communities from all other S. vermiculatus and T. tetrameres communities. The similar total biomass, diversity, and mole \% of all microbial groups highlighted the similarity of S. vermiculatus communities at Diverse and Old-growth. Based on the CA, all $S$. vermiculatus microbial communities in surface soils were similar, but biomass, diversity, and the distribution of all groups (except Gram-positive bacteria) suggested differences between $S$. vermiculatus communities. As indicated by the CA, A. tridentata communities in surface soils were relatively unique, having a higher proportion of Actinobacteria (4.9 mole \%) relative to all other shrub soils.

\subsection{Belowground characteristics and shrub communities}

In surface soils, shrub soil communities were influenced by $\mathrm{NO}_{3}^{-}$ concentrations and $\mathrm{pH}(P \leq 0.002)$ and, to a lesser extent, by $\mathrm{NH}_{4}^{+}$ concentrations and silt $(P \leq 0.02$, Fig. $5 A)$. In subsurface soils, shrub communities were associated with $\mathrm{P}$ and $\mathrm{Cl}$ concentrations 


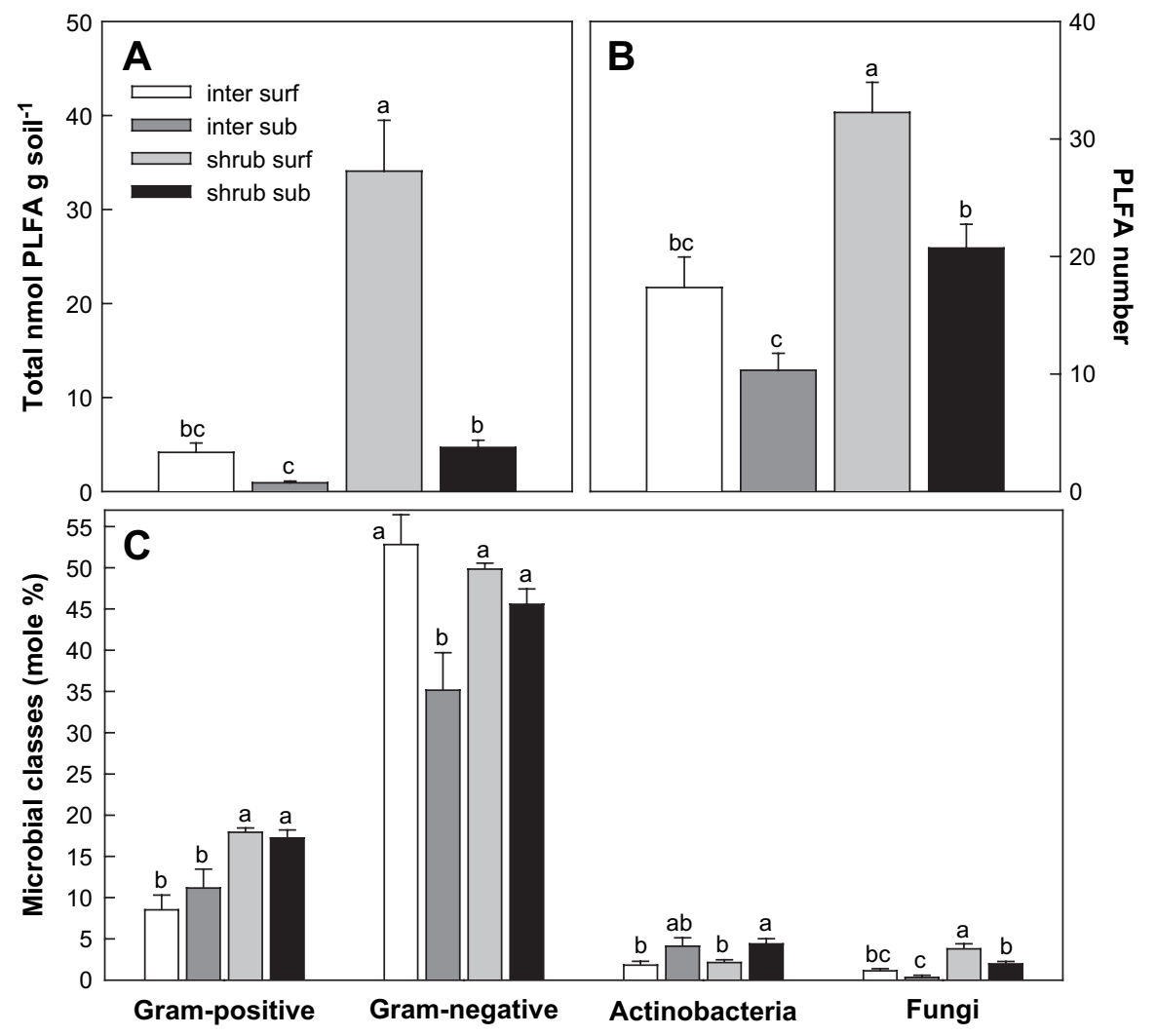

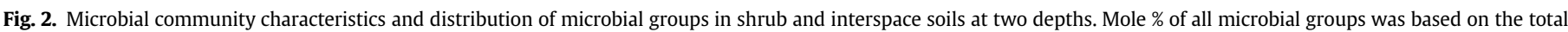
nmol PLFA g ${ }^{-1}$ soil. Values are means $(n=12-15)$ with standard error. Different letters indicate significant differences $(P \leq 0.05)$. For abbreviations see Fig. 1 .

$(P \leq 0.002)$, soil $\mathrm{N}(P \leq 0.02)$, and $\mathrm{NO}_{3}^{-}$concentrations $(P \leq 0.02$, Fig. 5B). Old-growth $S$. vermiculatus communities in surface soils were associated with higher $\mathrm{NO}_{3}^{-}$and $\mathrm{NH}_{4}^{+}$concentrations with values of $2.86 \mathrm{mg} \mathrm{NO}_{3}^{-} \mathrm{kg} \mathrm{soil}^{-1}, 2.67 \mathrm{mg} \mathrm{NH}_{4}^{+} \mathrm{kg} \mathrm{soil}^{-1}$ (Table 1).

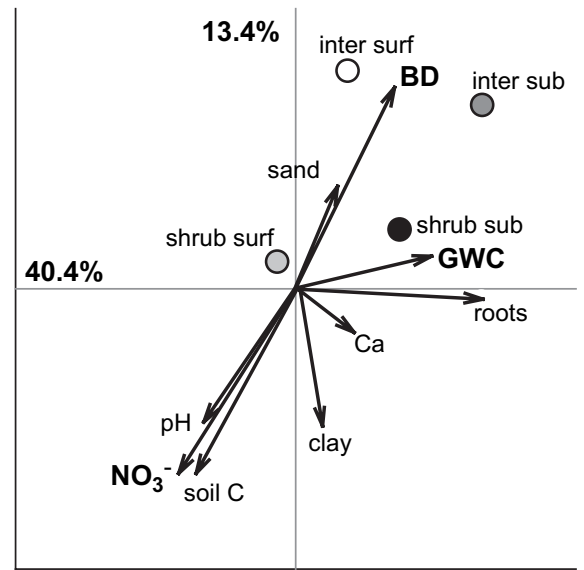

Fig. 3. Canonical correspondence analysis (CCA) results of shrub and interspace soil communities and belowground ecosystem characteristics. CCA included all 27 environmental characteristics, but only the eight characteristics having the greatest influence on microbial community composition (Monte Carlo permutation tests $P=0.002$ ) are depicted as black arrows. The direction of an arrow indicates the steepest increase in the variable, and the length indicates the strength relative to the other variables. Placement of shrub and interspace communities is based on mean CCA biplot scores. For all CCA plots, values on the $x$ and $y$ axes represent the percent variation explained by axis 1 and axis 2 respectively. Abbreviations for belowground characteristics include bulk density $=\mathrm{BD}$ and gravimetric water content $=\mathrm{GWC}$. For all other abbreviations see Fig. 1 .
Additionally in subsurface soils, Diverse $S$. vermiculatus communities were related to higher soil N, and T. tetrameres and A. tridentata communities were associated with higher concentrations of $\mathrm{NO}_{3}^{-}$. At both depths, soil $\mathrm{N}$ and inorganic $\mathrm{N}$ concentrations accounted for some of the variation between the microbial communities associated with axis 1 , which accounted for $31.4 \%$ and $41.5 \%$ of the explainable variation respectively. Soil nutrients other than $N$ influenced subsurface communities, in which A. tridentata and $T$. tetrameres soil communities were associated with low soil P. Soil $\mathrm{P}$ concentrations beneath these shrubs were 11.8 times lower in $A$. tridentata and 1.7 times lower in T. tetrameres soils compared to $S$. vermiculatus at their corresponding dunes. Further, Shadow $S$. vermiculatus microbial communities were correlated with higher $\mathrm{pH}$. This characteristic corresponded to axis 2, which explained $25.5 \%$ of the variation present in the shrub microbial communities. Deeper in shrub soils, higher $\mathrm{Cl}$ concentrations were most closely associated with $S$. vermiculatus communities at the two youngest dunes, which had $\mathrm{Cl}$ concentrations at least six-times those of any shrub soils at the older dunes.

\subsection{Microbial communities within interspace soils}

Interspace communities were generally distinct across the chronosequence in both surface and subsurface soils and were strongly influenced by dune development (Fig. 4C,D). Regardless of depth, all interspace communities were different. The only exception was surface communities present in the younger dunes (Transverse and Shadow), which were similar to one another. For both depths, the CA separated microbial communities by dune age and development along axis 1 , with the greatest amount of variation explained by axis $1(38.8 \%)$ in subsurface interspace communities. 
Table 1

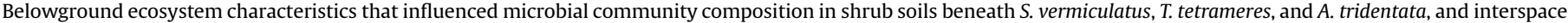
soils across MBERS

\begin{tabular}{|c|c|c|c|c|c|c|}
\hline & \multicolumn{2}{|l|}{ Interspace } & \multicolumn{4}{|l|}{ Shrub } \\
\hline & \multirow[b]{2}{*}{ Surf } & \multirow[b]{2}{*}{ Sub } & \multicolumn{2}{|c|}{ S. vermiculatus } & \multicolumn{2}{|c|}{ T. tetrameres at DD A. tridentata at OD } \\
\hline & & & Surf & Sub & Surf & Sub \\
\hline \multicolumn{7}{|c|}{ C and $N$} \\
\hline \multicolumn{7}{|c|}{ Roots ( $\mathrm{g} \mathrm{kg}^{-1}$ soil) } \\
\hline SD & 0 & & $0.01(0.003)$ & 0 & & \\
\hline TD & 0 & 0 & 0 & 0 & & \\
\hline DD & $0.01(0.004)$ & $0.10(0.034)$ & 0 & $0.28(0.117)$ & 0 & $0.15(0.028)$ \\
\hline OD & $0.01(0.001)$ & $0.05(0.007)$ & 0 & $0.08(0.020)$ & $0.09(0.052)$ & $0.10(0.04)$ \\
\hline \multicolumn{7}{|c|}{ Soil C ( $\mathrm{g} \mathrm{C} \mathrm{kg}^{-1}$ soil) } \\
\hline SD & $1.72(0.090)$ & & $2.00(0.092)$ & $2.33(0.098)$ & & \\
\hline TD & $1.68(0.073)$ & $1.53(0.097)$ & $1.81(0.131)$ & $1.91(0.106)$ & & \\
\hline DD & $1.98(0.089)$ & $1.83(0.132)$ & $4.00(0.726)$ & $3.02(0.296)$ & $4.88(0.446)$ & $3.10(0.239)$ \\
\hline OD & $2.97(0.115)$ & $2.93(0.487)$ & $6.01(0.720)$ & $4.34(0.819)$ & $5.07(0.935)$ & $2.51(0.249)$ \\
\hline \multicolumn{7}{|c|}{ Soil $\mathrm{N}$ ( $\mathrm{g} \mathrm{N} \mathrm{kg}^{-1}$ soil) } \\
\hline SD & $0.11(0.010)$ & & $0.11(0.014)$ & $0.12(0.019)$ & & \\
\hline TD & $0.10(0.004)$ & $0.10(0.006)$ & $0.14(0.014)$ & $0.16(0.006)$ & & \\
\hline DD & $0.20(0.010)$ & $0.17(0.010)$ & $0.54(0.089)$ & $0.31(0.037)$ & $0.43(0.035)$ & $0.30(0.027)$ \\
\hline OD & $0.26(0.021)$ & $0.21(0.038)$ & $0.78(0.100)$ & $0.37(0.053)$ & $0.35(0.041)$ & $0.18(0.026)$ \\
\hline $\mathrm{NH}_{4}^{+}$ & $\mathrm{kg}^{-1}$ soil) & & & & & \\
\hline SD & $0.16(0.098)$ & & $0.35(0.089)$ & $0.34(0.091)$ & & \\
\hline TD & $0.08(0.040)$ & $0.24(0.157)$ & $0.35(0.115)$ & $1.01(0.148)$ & & \\
\hline DD & $0.34(0.102)$ & 0 & $0.56(0.142)$ & $1.09(0.487)$ & $1.10(0.154)$ & $0.18(0.117)$ \\
\hline OD & $1.69(0.465)$ & $0.06(0.055)$ & $2.67(0.780)$ & $1.39(0.513)$ & $0.95(0.198)$ & $0.27(0.085)$ \\
\hline $\mathrm{NO}_{3}^{-}$ & $\mathrm{kg}^{-1}$ soil) & & & & & \\
\hline SD & $2.91(0.345)$ & & $3.98(0.740)$ & $2.77(1.26)$ & & \\
\hline TD & $1.30(0.168)$ & $0.96(0.201)$ & $4.22(0.597)$ & $8.71(1.75)$ & & \\
\hline DD & $0.83(0.093)$ & $0.23(0.067)$ & $11.9(1.71)$ & $3.66(0.695)$ & $7.37(0.932)$ & $2.03(0.222)$ \\
\hline OD & $0.49(0.240)$ & $1.86(0.716)$ & $2.86(0.460)$ & $2.20(0.205)$ & $1.84(0.371)$ & $0.30(0.137)$ \\
\hline Mac & utrients & & & & & \\
\hline Ca ( & & & & & & \\
\hline SD & $0.08(0.020)$ & & $0.12(0.018)$ & $0.08(0.007)$ & & \\
\hline TD & $0.13(0.012)$ & $0.09(0.009)$ & $0.14(0.022)$ & $0.14(0.008)$ & & \\
\hline DD & $0.64(0.079)$ & $0.45(0.135)$ & $0.43(0.058)$ & $0.79(0.163)$ & $1.31(0.146)$ & $0.98(0.256)$ \\
\hline OD & $2.52(0.742)$ & $0.85(0.131)$ & $1.04(0.159)$ & $1.64(0.480)$ & $2.68(0.943)$ & $1.22(0.257)$ \\
\hline $\mathrm{P}(\mathrm{m}$ & & & & & & \\
\hline SD & $0.55(0.086)$ & & $0.44(0.103)$ & $0.48(0.151)$ & & \\
\hline TD & $0.34(0.057)$ & $0.23(0.068)$ & $0.40(0.051)$ & $0.48(0.049)$ & & \\
\hline DD & $0.05(0.009)$ & $0.04(0.007)$ & $0.38(0.059)$ & $0.48(0.068)$ & $0.33(0.073)$ & $0.27(0.016)$ \\
\hline OD & $0.03(0.006)$ & $0.07(0.025)$ & $0.70(0.215)$ & $0.83(0.184)$ & $0.12(0.036)$ & $0.07(0.024)$ \\
\hline Phys & & & & & & \\
\hline Bulk & $\left.1^{-3}\right)$ & & & & & \\
\hline SD & $1.39(0.013)$ & & $1.34(0.025)$ & $1.19(0.051)$ & & \\
\hline TD & $1.33(0.018)$ & $1.28(0.028)$ & 1.27 (0.019) & $1.19(0.033)$ & & \\
\hline DD & $1.34(0.035)$ & $1.27(0.030)$ & $1.06(0.054)$ & $1.08(0.028)$ & $1.15(0.034)$ & $1.15(0.034)$ \\
\hline OD & $1.33(0.014)$ & $1.30(0.036)$ & $1.00(0.049)$ & $1.12(0.014)$ & $1.23(0.030)$ & $1.20(0.026)$ \\
\hline Clay & & & & & & \\
\hline SD & $0.70(0.037)$ & & $0.71(0.064)$ & $0.76(0.074)$ & & \\
\hline TD & $0.59(0.024)$ & $0.53(0.018)$ & $0.66(0.034)$ & $0.64(0.034)$ & & \\
\hline DD & $0.87(0.022)$ & $0.96(0.056)$ & $0.98(0.041)$ & $0.97(0.029)$ & $0.99(0.044)$ & $0.97(0.048)$ \\
\hline OD & $1.03(0.017)$ & $1.29(0.080)$ & $1.10(0.065)$ & $1.22(0.105)$ & $1.13(0.098)$ & $0.96(0.070)$ \\
\hline Grav & content ( $\mathrm{g} \mathrm{H}_{2}$ & & & & & \\
\hline SD & $0.02(0.003)$ & & $0.02(0.003)$ & $0.09(0.015)$ & & \\
\hline TD & $0.01(0.003)$ & $0.05(0.010)$ & $0.02(0.008)$ & $0.05(0.005)$ & & \\
\hline DD & $0.01(0.001)$ & $0.05(0.004)$ & $0.01(0.000)$ & $0.03(0.002)$ & $0.01(0.001)$ & $0.03(0.003)$ \\
\hline OD & $0.01(0.001)$ & $0.03(0.003)$ & $0.01(0.002)$ & $0.03(0.003)$ & $0.01(0.001)$ & $0.02(0.004)$ \\
\hline Sanc & & & & & & \\
\hline SD & $96.0(0.235)$ & & $95.8(0.546)$ & $94.8(0.611)$ & & \\
\hline TD & $96.3(0.222)$ & $96.5(0.086)$ & $96.6(0.186)$ & $96.7(0.160)$ & & \\
\hline DD & $95.1(0.133)$ & $96.8(0.616)$ & $93.6(0.631)$ & $94.6(0.429)$ & $93.9(0.272)$ & $94.6(0.426)$ \\
\hline OD & $93.1(0.218)$ & $91.2(1.13)$ & $92.6(0.737)$ & $91.3(1.170)$ & $91.3(1.22)$ & $92.9(0.479)$ \\
\hline Silt & & & & & & \\
\hline SD & $3.3(0.202)$ & & 3.5 (0.489) & $4.4(0.540)$ & & \\
\hline TD & $3.1(0.203)$ & $2.9(0.076)$ & $2.8(0.156)$ & $2.7(0.130)$ & & \\
\hline DD & $4.0(0.118)$ & $2.3(0.579)$ & $5.4(0.593)$ & $4.4(0.402)$ & $5.1(0.232)$ & $4.5(0.378)$ \\
\hline OD & $5.9(0.212)$ & 7.5 (1.07) & $6.3(0.695)$ & 7.5 (1.07) & $7.6(1.142)$ & $6.1(0.410)$ \\
\hline Stres & & & & & & \\
\hline $\mathrm{B}(\mathrm{n}$ & & & & & & \\
\hline SD & $12.9(1.66)$ & & 7.97 (1.769) & 9.08 (1.514) & & \\
\hline TD & 8.41 (1.377) & $6.43(1.605)$ & $6.80(0.899)$ & 8.25 (1.392) & & \\
\hline DD & $0.27(0.050)$ & $0.17(0.013)$ & $0.73(0.098)$ & $0.70(0.057)$ & $0.89(0.133)$ & $0.75(0.135)$ \\
\hline & & & & & & on next page) \\
\hline
\end{tabular}


Table 1 (continued)

\begin{tabular}{|c|c|c|c|c|c|c|}
\hline & \multicolumn{2}{|l|}{ Interspace } & \multicolumn{4}{|l|}{ Shrub } \\
\hline & \multirow[b]{2}{*}{ Surf } & \multirow[b]{2}{*}{ Sub } & \multicolumn{2}{|l|}{ S. vermiculatus } & \multicolumn{2}{|c|}{ T. tetrameres at DD A. tridentata at OD } \\
\hline & & & Surf & Sub & Surf & Sub \\
\hline OD & $0.10(0.021)$ & $0.07(0.011)$ & $0.35(0.068)$ & $0.41(0.090)$ & $0.19(0.038)$ & $0.14(0.033)$ \\
\hline \multicolumn{7}{|c|}{$\mathrm{Cl}\left(\mathrm{mmol} \mathrm{L}^{-1}\right)$} \\
\hline SD & $217(46.7)$ & & $54.7(11.9)$ & $74.5(18.1)$ & & \\
\hline TD & $101(27.2)$ & $33.1(9.07)$ & $45.1(4.60)$ & $97.5(23.4)$ & & \\
\hline DD & $2.92(0.663)$ & $1.67(0.836)$ & $8.61(1.72)$ & $11.9(1.51)$ & $11.5(2.17)$ & $6.43(1.48)$ \\
\hline OD & $0.92(0.117)$ & $1.42(0.576)$ & $13.3(3.60)$ & $8.39(2.43)$ & $2.52(0.779)$ & $2.02(0.576)$ \\
\hline \multicolumn{7}{|l|}{$\mathrm{pH}$} \\
\hline SD & $10.0(0.060)$ & & $10.0(0.188)$ & $10.0(0.128)$ & & \\
\hline TD & $9.9(0.155)$ & $9.8(0.227)$ & $9.9(0.157)$ & $10.3(0.093)$ & & \\
\hline DD & $7.7(0.099)$ & $7.8(0.118)$ & $9.3(0.240)$ & $9.1(0.046)$ & $8.5(0.168)$ & $8.4(0.117)$ \\
\hline OD & $7.6(0.263)$ & $7.6(0.150)$ & $9.8(0.226)$ & $9.5(0.347)$ & $7.6(0.194)$ & $7.9(0.276)$ \\
\hline
\end{tabular}

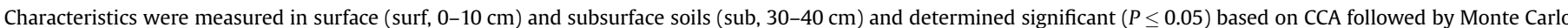

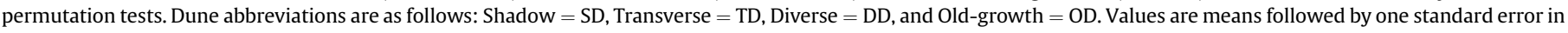
parentheses $(n=4-5)$.

The patterns described by the CA of interspace soil communities were reflected in communities' biomass and diversity, and the four microbial groups in both surface and subsurface soils (Fig. 4C,D, Table 2). In surface soils, Shadow and Transverse interspace communities were similar. These communities had lower biomass and diversity, no Actinobacteria or fungi, and very little Gram-positive bacteria compared to the older interspace communities. In subsurface soils, the distinctness of all interspace communities was demonstrated by PLFA number, which increased with dune age.
Communities at Transverse were different from those at the two older dunes, with a higher mol \% of Gram-negative bacteria and no Actinobacteria and Gram-positive bacteria.

\subsection{Belowground characteristics and interspace communities}

Differences in interspace soil communities across the chronosequence were primarily associated with B concentration $(P=0.002)$ at both soil depths and by \% sand $(P=0.008)$ and $\mathrm{Cl}$
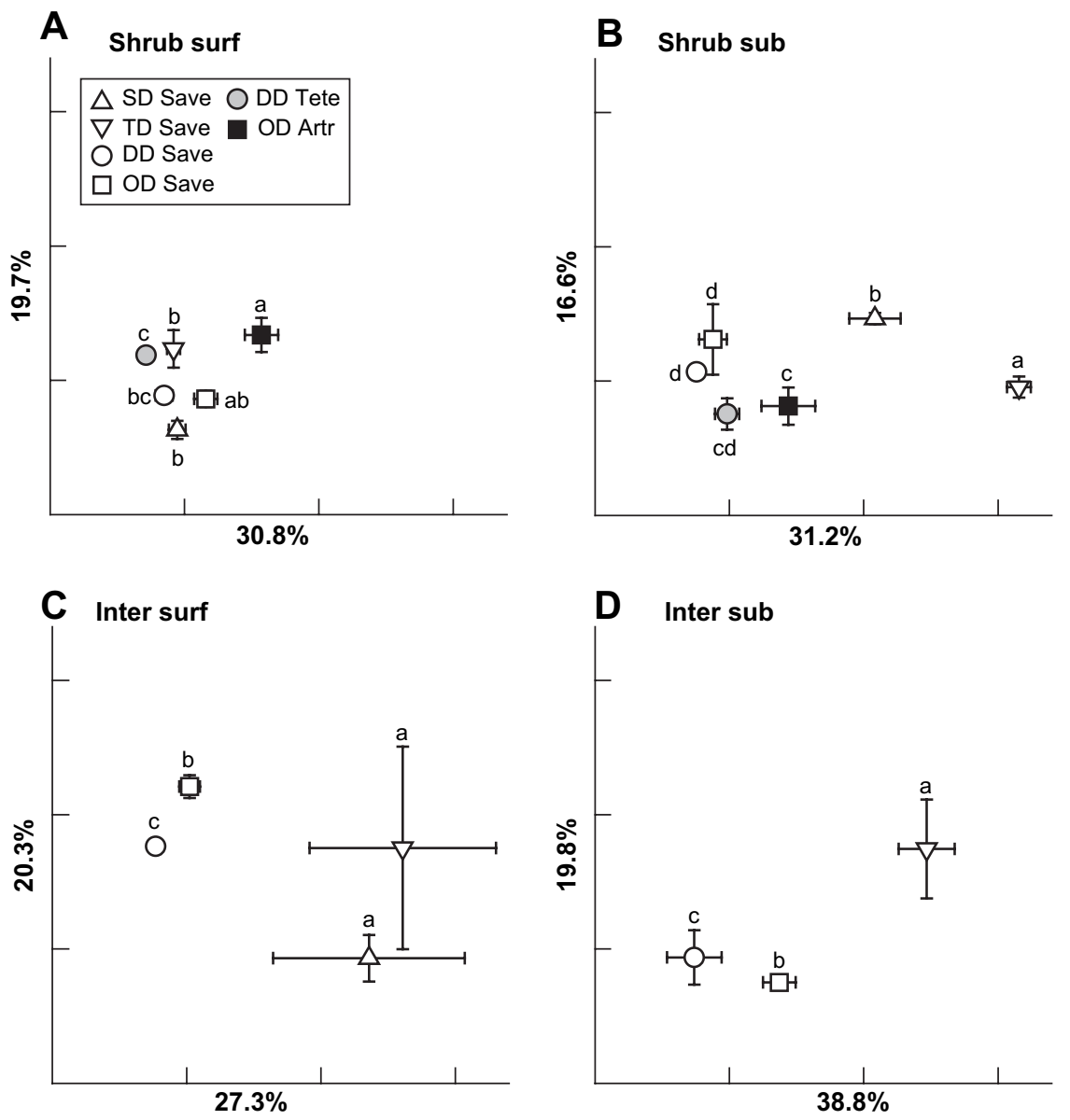

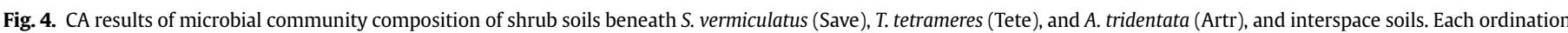

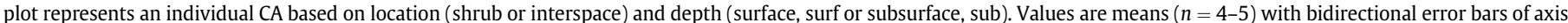
1 and 2. Different letters indicate significant differences $(P \leq 0.05)$ between communities across axis 1 . For dune abbreviations see Table 1 . 
Table 2

Microbial community characteristics and the distribution of microbial groups in shrub and interspace soils

\begin{tabular}{|c|c|c|c|c|c|c|}
\hline & SD & TD & DD (Save) & DD (Tete) & OD (Save) & OD (Artr) \\
\hline \multicolumn{7}{|c|}{ Total nmol PLFA g soil ${ }^{-1}$} \\
\hline Inter surf & $0.58 \mathrm{~b}$ & $0.52 \mathrm{~b}$ & $6.75 \mathrm{a}$ & & $8.80 \mathrm{a}$ & \\
\hline Inter sub & & $0.37 \mathrm{~b}$ & $1.94 \mathrm{a}$ & & $1.08 \mathrm{a}$ & \\
\hline Shrub surf & $3.74 \mathrm{~cd}$ & $1.23 \mathrm{~d}$ & $54.7 \mathrm{ab}$ & $41.1 \mathrm{ab}$ & 63.1a & $26.4 \mathrm{bc}$ \\
\hline Shrub sub & $1.26 \mathrm{bc}$ & $0.54 \mathrm{c}$ & 9.65 a & $6.38 \mathrm{ab}$ & $3.05 \mathrm{ab}$ & $7.96 \mathrm{ab}$ \\
\hline \multicolumn{7}{|c|}{ PLFA number } \\
\hline Inter surf & $7.0 \mathrm{~b}$ & $6.4 \mathrm{~b}$ & $26.4 \mathrm{a}$ & & 29.6 a & \\
\hline Inter sub & & $6.0 \mathrm{c}$ & $17.6 \mathrm{a}$ & & $13.3 \mathrm{~b}$ & \\
\hline Shrub surf & $17.3 \mathrm{~b}$ & $9.8 \mathrm{~b}$ & $40.4 \mathrm{a}$ & $37.0 \mathrm{a}$ & $44.6 \mathrm{a}$ & $38.3 \mathrm{a}$ \\
\hline Shrub sub & $10.0 \mathrm{bc}$ & $7.0 \mathrm{c}$ & $30.3 \mathrm{a}$ & $27.4 \mathrm{a}$ & $30.4 \mathrm{a}$ & $21.3 \mathrm{ab}$ \\
\hline \multicolumn{7}{|c|}{ Gram-positive bacteria (mole \%) } \\
\hline Inter surf & $0 \mathrm{~b}$ & $2.38 \mathrm{~b}$ & $16.7 \mathrm{a}$ & & $15.0 \mathrm{a}$ & \\
\hline Inter sub & & $0 \mathrm{~b}$ & $21.0 \mathrm{a}$ & & $17.0 \mathrm{a}$ & \\
\hline Shrub surf & $19.9 \mathrm{a}$ & $16.7 \mathrm{ab}$ & $18.5 \mathrm{ab}$ & $18.0 \mathrm{ab}$ & $18.8 \mathrm{ab}$ & $15.4 \mathrm{~b}$ \\
\hline Shrub sub & $13.8 \mathrm{~b}$ & $13.9 \mathrm{~b}$ & 20.9 a & $19.5 \mathrm{a}$ & 19.2 a & $16.7 \mathrm{ab}$ \\
\hline \multicolumn{7}{|c|}{ Gram-negative bacteria (mole \%) } \\
\hline Inter surf & 63.3 & 47.6 & 53.6 & & 46.8 & \\
\hline Inter sub & & $57.3 \mathrm{a}$ & $35.6 \mathrm{~b}$ & & $35.5 \mathrm{~b}$ & \\
\hline Shrub surf & $55.4 \mathrm{a}$ & $51.0 \mathrm{ab}$ & $49.4 \mathrm{~b}$ & $49.1 \mathrm{~b}$ & $47.9 \mathrm{~b}$ & $47.1 \mathrm{~b}$ \\
\hline Shrub sub & $60.2 \mathrm{a}$ & $48.5 \mathrm{~b}$ & $39.1 \mathrm{c}$ & $40.6 \mathrm{c}$ & $39.4 \mathrm{c}$ & 44.2 bc \\
\hline \multicolumn{7}{|c|}{ Actinobacteria (mole \%) } \\
\hline Inter surf & $0 \mathrm{c}$ & $0 \mathrm{c}$ & $2.56 \mathrm{~b}$ & & $4.72 \mathrm{c}$ & \\
\hline Inter sub & & $0 \mathrm{~b}$ & $8.25 \mathrm{a}$ & & $8.21 \mathrm{a}$ & \\
\hline Shrub surf & $0.96 \mathrm{~cd}$ & $0 \mathrm{~d}$ & $2.16 \mathrm{bc}$ & $2.30 \mathrm{bc}$ & $2.39 \mathrm{~b}$ & $4.89 \mathrm{a}$ \\
\hline Shrub sub & $0.32 \mathrm{~b}$ & $0 \mathrm{~b}$ & $8.22 \mathrm{a}$ & $6.83 a$ & $6.11 \mathrm{a}$ & $5.80 \mathrm{a}$ \\
\hline \multicolumn{7}{|c|}{ Fungi (mole \%) } \\
\hline Inter surf & $0 \mathrm{~b}$ & $0 \mathrm{~b}$ & $2.23 \mathrm{a}$ & & $2.26 \mathrm{a}$ & \\
\hline Inter sub & & $0 \mathrm{~b}$ & $1.22 \mathrm{a}$ & & $0 \mathrm{~b}$ & \\
\hline Shrub surf & $1.05 \mathrm{a}$ & $5.99 \mathrm{~b}$ & $3.17 \mathrm{ab}$ & $4.78 \mathrm{ab}$ & $3.46 \mathrm{ab}$ & $4.31 \mathrm{ab}$ \\
\hline Shrub sub & $0.45 \mathrm{bc}$ & $0 \mathrm{c}$ & $2.06 \mathrm{ab}$ & $3.28 \mathrm{a}$ & $2.50 \mathrm{a}$ & $3.95 \mathrm{a}$ \\
\hline
\end{tabular}

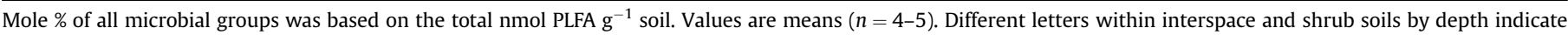
significant differences $(P \leq 0.05)$. For dune abbreviations see Table 1 and shrub soil abbreviation see Fig. 4 .

concentrations $(P=0.04)$ in surface soils and by \% silt $(P=0.004)$ in subsurface (Fig. 5C,D). In Shadow surface soils and in Transverse soils at both depths, interspace communities were associated with high $B$ concentrations, which ranged from $12.9 \mathrm{mmol} \mathrm{L}^{-1}$ in Shadow at $10 \mathrm{~cm}$ to $6.43 \mathrm{mmol} \mathrm{L}^{-1}$ in Transverse at $40 \mathrm{~cm}$ (Table 1 ). Besides B, high concentrations of $\mathrm{Cl}(P=0.04)$ in the two younger dunes were associated with Shadow and Transverse communities. Transverse and Shadow interspace communities in surface soils were associated loosely with more sandy soils, while Old-growth interspace communities in subsurface soils were associated with siltier soils.

Ten of the 27 belowground characteristics investigated did not influence microbial community composition. Across the chronosequence, the grand mean of these characteristics ( $n=94$, followed by one standard error), listed by category, was: $\mathrm{C}$ and $\mathrm{N}$ availabilitylitter $\mathrm{C}=0.17 \pm 0.02 \mathrm{~g} \mathrm{C} \mathrm{kg}^{-1}$ soil and litter $\mathrm{N}=5.96 \pm 0.87 \mu \mathrm{g} \mathrm{C}$ $\mathrm{kg}^{-1}$ soil; macro and micronutrients $-\mathrm{Fe}=7.01 \pm 1.42 \mu \mathrm{mol} \mathrm{L} \mathrm{L}^{-1}$, $\mathrm{K}=4.66 \pm 0.52 \mathrm{mmol} \mathrm{L}^{-1}, \mathrm{~S}=5.42 \pm 0.61 \mathrm{mmol} \mathrm{L}^{-1}$, and $\mathrm{Zn}=$ $0.23 \pm 0.03 \mu \mathrm{mol} \mathrm{L}^{-1}$; and potential stresses-electrical conductivity $=6.46 \pm 0.89 \mathrm{dSm}^{-1}, \mathrm{Na}=49.0 \pm 5.79 \mathrm{mmol} \mathrm{L}^{-1}$, sodium adsorption ratio $=114 \pm 16.9$, and alkalinity from carbonates $=$ $7.66 \pm 0.91$.

\section{Discussion}

\subsection{Communities between shrub and interspace soils}

As hypothesized, microbial community composition differed between shrub and interspace soils, and total soil $\mathrm{C}$ and $\mathrm{NO}_{3}^{-}$ availability were two major factors differentiating microbial communities. Despite considerable spatio-temporal variation present across the chronosequence, communities could be combined into four dominant groups, reflecting shrub presence versus absence and surface versus subsurface soils. Interspace soil communities were associated with lower soil $\mathrm{C}$ and $\mathrm{NO}_{3}^{-}$concentrations and relative to shrub soil communities, by surface or subsurface soils, supported lower microbial biomass, diversity, and less fungi and Gram-positive bacteria. Just as the lower soil $\mathrm{C}$ and $\mathrm{N}$ in interspace soils have been linked to lower $\mathrm{C}$ and $\mathrm{N}$ mineralization rates and microbial biomass in other deserts (Gallardo and Schlesinger, 1992; Schaeffer et al., 2003; Schaeffer and Evans, 2005), the relatively lower soil $\mathrm{C}$ and $\mathrm{N}$ in interspace soils across MBERS were also linked to less diverse and compositionally different microbial communities. Similar to our study, Sonoran Desert microbial communities differed between shrub and interspace soils, especially in low elevation areas where the distance between shrub and interspaces was high (Collins and Cavigelli, 2003).

Differences in ecosystem characteristics associated with soil depth (i.e., presence of roots and higher gravimetric water content) were of major importance in differentiating microbial communities across the chronosequence. Microbial communities in shrub subsurface soils were associated with root presence, but it is unclear how roots influenced community composition. Across the chronosequence, roots (both live and dead) are localized in subsurface relative to surface soils. Roots were not solely a $C$ source and root presence was not correlated with total soil C in the CCA. Instead, root presence was associated with higher soil moisture, likely due to their role in redistributing soil moisture via transpiration and shrub-induced hydraulic redistribution processes (Richards and Caldwell, 1987; Caldwell et al., 1998). Regardless of these potential differences induced by shrub presence, subsurface soils were wetter than surface soils across the chronosequence at the time of 

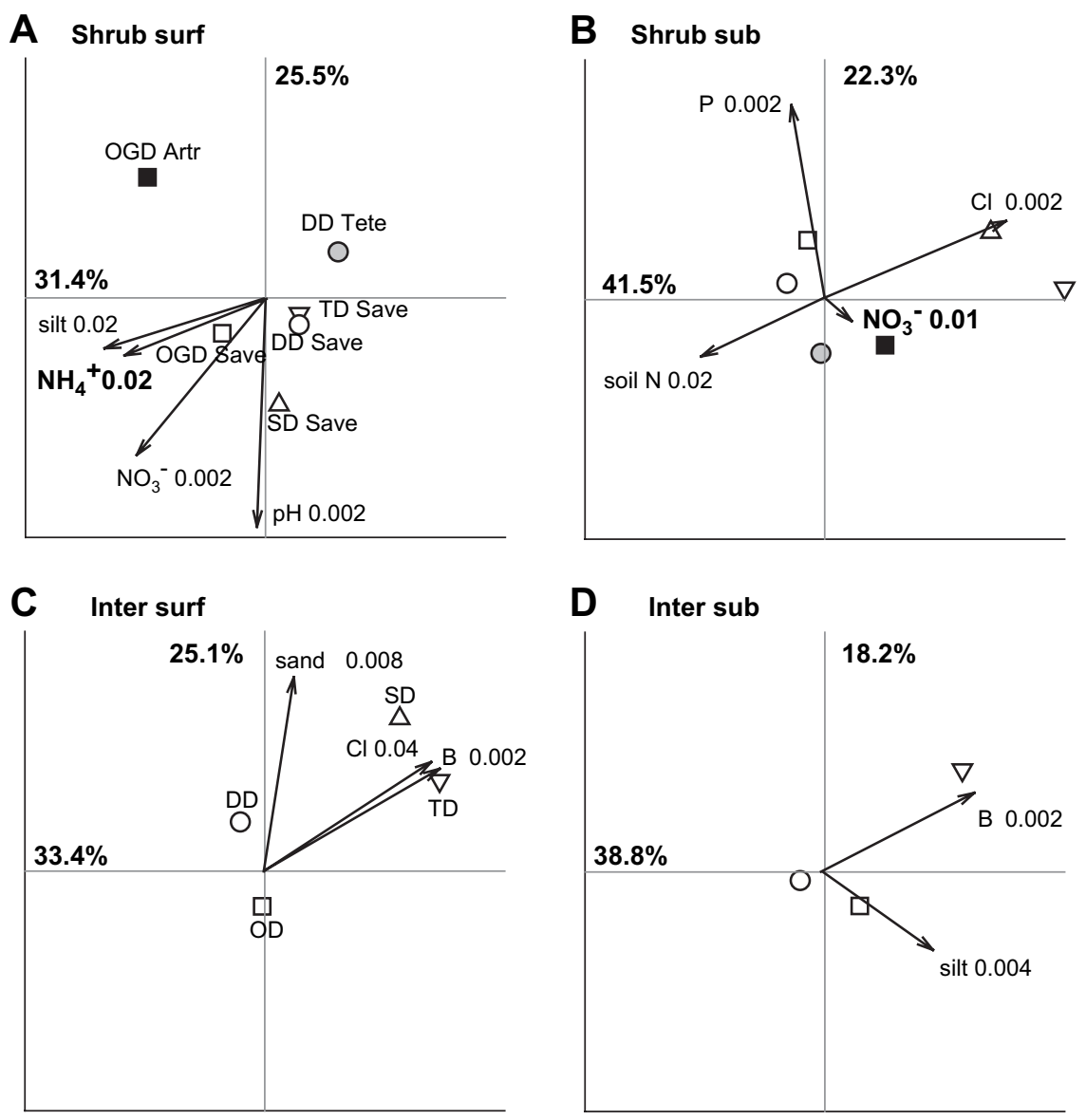

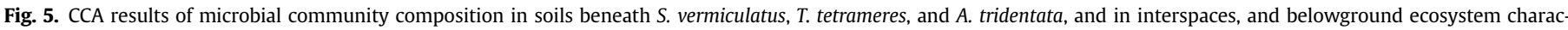

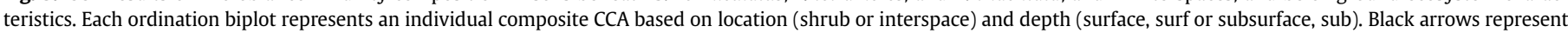

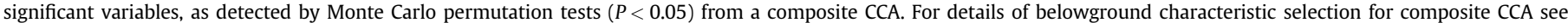
Section 2.4. Placement of shrub and interspace communities is based on mean CCA biplot scores. For abbreviations see Fig. 4 .

harvest in July and throughout the growing season (data not shown). Desert surface soils are subject to longer periods of drought and higher fluctuations in soil moisture than are subsurface soils (Reynolds et al., 1999), and thus may select for microbial communities that can tolerate drier surface soils.

Distributions of Gram-positive bacteria and Actinobacteria (which are also Gram-positive) demonstrated the most specificity to shrub relative to interspace soils across the chronosequence and helped differentiate shrub communities at both soil depths. For example, Gram-positive bacterial fatty acids i15:0, i16:0, i17:0, and a17:0 occurred in $S$. vermiculatus soils but not in interspace soils at Shadow and Transverse. Further, i14:0, another fatty acid associated with Gram-positive bacteria, exclusively occurred in surface shrub soils at Diverse and Old-growth. Therefore, in less than 47 years of shrub establishment, the presence of a shrub alters belowground characteristics enough to allow microbial community composition to shift. Actinobacteria, the fatty acids 10Me16:0, 10Me17:0, and 10Me18:0, predominantly occurred in shrub soils of the two oldest dunes. However, 10Me17:0, and 10Me18:0 also were present in interspace surface soils at Old-growth, and 10Me16:0 was present in Old-growth and Diverse interspace soils. Actinobacteria often are associated with the rhizosphere of plants and shrub species in desert soils (Vollmer et al., 1977; Basil et al., 2004). Similarly, Ewing et al. (2007) found Actinobacteria concentrations to decline with increasing distance from long-lived Larrea tridentata shrubs (individuals may exist for several thousand years) but still persist in interspace soils adjacent to this shrub species in the Mojave Desert. Thus, it may require hundreds of years for shrub species to alter interspace characteristics enough to impact interspace community composition.

The distribution of fungi across the chronosequence also helped differentiate microbial communities between shrub and interspace soils, with fungi not being detected in interspace soils of the two youngest dunes. Fungi in shrub and interspace soils were most likely basidiomycetes (J.H. Richards personal observation) and not mycorrhizae, except in deeper $T$. tetrameres and A. tridentata soils (Caldwell et al., 1985). S. vermiculatus, like many other chenopods (Pendleton and Smith, 1983), is non-mycorrhizal and revealed no evidence of mycorrhizal colonization after staining and inspection (personal observation).

\subsection{Communities within shrub soils}

As hypothesized, microbial communities in shrub soils were associated with specific shrub species, and these differences were linked to factors other than organic C source availability. For example, microbial communities associated with $S$. vermiculatus in surface soils had very similar composition, regardless of placement along the chronosequence. This chronosequence spanned $\approx 3000$ years of dune development and almost a 16 -fold increase in total microbial biomass. Furthermore, considering the separation of subsurface communities along axis 2 of the CA, communities in $S$. vermiculatus subsurface soils, across the entire chronosequence, were distinct from the communities associated with the two other shrub species. S. vermiculatus is a halophyte, tolerating high soil salinity, $\mathrm{pH}, \mathrm{EC}$, and B, and it accumulates salts in its leaves (Donovan 
et al., 1996, 1997; Donovan and Richards, 2000). In contrast, neither A. tridentata nor T. tetrameres are halophytes, and both are less tolerant of soil stresses. Shrub-specific microbial community composition may reflect species-specific differences in leaf chemistry or nutrient utilization patterns that alter soil characteristics, and/or indicate that particular ecosystem stresses were similarly important in structuring shrub and microbial communities alike.

Contrary to our hypothesis, community differences were associated with soil $\mathrm{N}$ factors. Beneath shrub species, microbial communities were influenced by $\mathrm{NO}_{3}^{-}$and $\mathrm{NH}_{4}^{+}$concentrations in surface soils and $\mathrm{NO}_{3}^{-}$and soil $\mathrm{N}$ in subsurface soils. Microbial $\mathrm{N}$ dynamics are often plant species-specific and intensify with the accumulation of soil C (Chen and Stark, 2000; Schaeffer et al., 2003; Schaeffer and Evans, 2005). In the older dunes, as shrub soils accumulated C, communities in $T$. tetrameres and $A$. tridentata soils were similar in their relationships to $\mathrm{N}$ characteristics, but opposite to how $S$. vermiculatus soil communities related to $\mathrm{N}$ characteristics. Soil communities beneath the two non-halophytic species were related to lower inorganic $\mathrm{N}$ concentrations, especially $T$. tetrameres, in surface soils and to higher $\mathrm{NO}_{3}^{-}$concentrations in subsurface soils. Even with the microbial community and $\mathrm{N}$ relationships reversing between the surface and subsurface, $T$. tetrameres and $A$. tridentata soils were almost always lower in $\mathrm{N}$ availability compared to $S$. vermiculatus soils. This observation suggests shrub-specific microbial communities may be due partially to microbial $\mathrm{N}$ limitation induced not only during dune development but also by higher inorganic $\mathrm{N}$ use by $T$. tetrameres and $A$. tridentata than $S$. vermiculatus shrub species.

Microbial communities in $T$. tetrameres and $A$. tridentata soils were associated with lower soil $\mathrm{P}$ in subsurface soils, thus suggesting potential P-limitation for these communities. Soil $\mathrm{P}$ concentrations beneath $T$. tetrameres and $A$. tridentata shrubs were at least half as much as those measured beneath $S$. vermiculatus. From the perspective of the shrub species, P-limitations were observed in Chrysothamnus nauseosus (Asteraceae) at Diverse and Old-growth (Drenovsky and Richards, 2006). Although this shrub species was not included in our study, we sampled soils beneath two other members of the Asteraceae family: T. tetrameres and A. tridentata. The possible P-limitations associated with these species may have depleted soil $\mathrm{P}$ and induced microbial $\mathrm{P}$ limitations, thus selecting for microorganisms adapted to low P conditions.

\subsection{Communities within interspace soils}

Contrary to our hypothesis, interspace community composition varied across the landscape, but, as hypothesized, communities were associated with characteristics other than $\mathrm{C}$ and $\mathrm{N}$. The clear separation of microbial communities in interspace soils was unexpected due to the universally low levels of microbial biomass and diversity in interspace soils (Collins and Cavigelli, 2003; Ewing et al., 2007) across the chronosequence. The separation of interspace communities in both surface and subsurface soils was primarily associated with soil stresses, especially B. High soil B concentrations seemed to negatively impact Shadow and Transverse microbial communities at both depths. These communities sustained lower levels of microbial biomass and diversity relative to older dune interspace communities. Although other ecosystem stresses and factors contributed to the separation of the younger dune microbial communities, this is the first field evidence that we are aware of demonstrating the potential toxicity of B to microorganisms. Concentrations of B are relatively higher in desert soils compared to the soils of other ecosystems, and B may interfere with DNA methylation (Benkovic et al., 2005).

In interspace soils, soil texture was both a stress and benefit to soil microbial community composition. For example, the greater \% sand of the younger dunes correlated with interspace communities of relatively low biomass and diversity, while greater \% silt of Oldgrowth correlated with shrub and interspace communities of high biomass and species diversity. This is a common pattern in soils. Finer textured soils create environments that sustain microbial communities with higher biomass and a diversity due to protecting and accumulating soil $\mathrm{C}$ and other macro- and micronutrients (Sessitsch et al., 2001; Acosta-Martinez et al., 2003). This also was true of interspace soils, as the soil texture became finer soil C increased. Besides differences in C, finer texture soils may offer more protectedsites for microbial attachment and increase soil moisture availability.

\subsection{Soil stresses and communities}

As hypothesized, microbial communities in the relatively younger dunes were primarily structured by soil stresses, and as dunes aged, the influence of these stresses on microbial community composition decreased and the importance of other factors (namely inorganic $\mathrm{N}$ and total soil $\mathrm{N}$ ) increased. In all CCA, regardless of being from shrub or interspace soils, the impact of soil stresses (i.e., $\mathrm{B}, \mathrm{Cl}$, and $\mathrm{pH}$ ) was evident with the higher intensity of soil stresses associated with the two youngest dunes' microbial communities. Soil stresses dramatically declined after $\approx 300$ years of dune development. For example, from Transverse to Diverse soils, B concentrations decreased 24-fold and nine-fold, and $\mathrm{Cl}$ concentrations decreased 11 -fold and four-fold in interspace and shrub soils respectively. These stresses across the landscape were alleviated as shrub species, predominantly $S$. vermiculatus, created biogenic dunes, allowing leaching of $\mathrm{B}$ and $\mathrm{Cl}$ through the soil profile during snow melt and precipitation events (Vasek and Lund, 1980; Toft and Elliott-Fisk, 2002).

High $\mathrm{Cl}$ (anion for $\mathrm{Na}$ ) concentrations and other elements associated with salinity and sodicity induce bacterial osmotic stress (Brown, 1976). This osmotic stress selects for halophilic bacteria, chiefly Gram-negative bacteria, which can survive and thrive in hypersaline environments. All of the Gram-negative bacteria fatty acids, except 16:012OH and 17:0, were measured frequently in all Shadow and Transverse soils. However, there was not one fatty acid, Gram-negative or otherwise, that solely appeared in Shadow and Transverse soils. Therefore, we believe that although the Gramnegative bacteria present in Shadow and Transverse are halophilic, they are not restricted to the hypersaline soil conditions of the two youngest dunes. Gram-negative bacteria produce a lipopolysaccharide outer membrane, which allows them to adhere to coarse sand particles, withstand dynamic fluctuations in soil moisture, and counteract soil stresses (Sylvia et al., 1998; Kaur et al., 2005). These characteristics make Gram-negative bacteria ideal to withstand most stresses across MBERS and may account for their dominance across the chronosequence. This group consistently equaled no less than $47 \%$ of the community in Shadow and Transverse soils and $35 \%$ in all other soils.

In conclusion, microbial community composition differed between shrub and interspace soils despite considerable spatiotemporal variation across the chronosequence, and soil $\mathrm{C}$ and $\mathrm{NO}_{3}^{-}$ availability were two major factors differentiating microbial communities. Once these clear differences in community composition and soil characteristics between shrub and interspace soils were removed, shrub and interspace communities were associated with characteristics other than those relating to soil C. Within shrub soils, microbial community composition was associated with specific shrub species and dune development, and composition was primarily regulated by $\mathrm{N}$ and $\mathrm{P}$ availability and soil stresses. Within interspace soils, community composition surprisingly varied with dune development, and communities were influenced exclusively by soil stresses. Of the 27 belowground characteristics investigated, 13 separated shrub from interspace communities, seven separated shrub communities, and four separated interspace communities. Of 
the 13 that separated shrub from interspace communities, only five emerged as factors influencing community composition within shrub and interspace soils. Two of these five characteristics were related to $\mathrm{N}$ (i.e., $\mathrm{NO}_{3}^{-}$and $\mathrm{NH}_{4}^{+}$availability), demonstrating the universal relationship between microbial communities and $\mathrm{N}$ availability across the chronosequence. This research captures the sensitivity of microbial communities to belowground heterogeneity throughout the soil profile, while highlighting how specific shrub species and ecosystem development alter relationships between microbial community composition and ecosystem characteristics.

\section{Acknowledgments}

We thank the Kearney Foundation of Soil Science (Grant \#2003.316) for funding this research. Also, we thank Dr. Kate M. Scow's lab at the University of California, Davis for analyzing PLFA samples and Dr. Ana Lucía Córdova-Kreylos for her help with multivariate statistics.

\section{References}

Acosta-Martinez, V., Klose, S., Zobeck, T.M., 2003. Enzyme activities in semiarid soils under conservation reserve program, native rangeland, and cropland. Journal of Plant Nutrition and Soil Science 166, 699-707.

Basil, A., Strap, J.L., Knotek-Smith, H.M., Crawford, D.L., 2004. Studies on the microbial populations of the rhizosphere of big sagebrush (Artemisia tridentata). Journal of Industrial Microbiology \& Biotechnology 31, 278-288.

Benkovic, S.J., Baker, S.J., Alley, M.R.K., Woo, Y.H., Zhang, Y.K., Akama, T., Mao, W.M., Baboval, J., Rajagopalan, P.T.R., Wall, M., Kahng, L.S., Tavassoli, A., Shapiro, L., 2005. Identification of borinic esters as inhibitors of bacterial cell growth and bacterial methyltransferases, CcrM and MenH. Journal of Medicinal Chemistry 48, 7468-7476.

Bligh, E.G., Dyer, W.J., 1959. A rapid method of total lipid extraction and purification. Canadian Journal of Biochemistry and Physiology 37, 911-917.

Blume, E., Bischoff, M., Reichert, J.M., Moorman, T., Konopka, A., Turco, R.F., 2002. Surface and subsurface microbial biomass, community structure and metabolic activity as a function of soil depth and season. Applied Soil Ecology 20,171-181.

Bossio, D.A., Scow, K.M., 1998. Impacts of carbon and flooding on soil microbial communities: phospholipid fatty acid profiles and substrate utilization patterns. Microbial Ecology 35, 265-278.

Brown, A.D., 1976. Microbial water stress. Bacteriological Reviews 40, 803-846.

Caldwell, M.M., Eissenstat, D.M., Richards, J.H., Allen, M.F., 1985. Competition for phosphorus-differential uptake from dual-isotope labeled soil interspaces between shrub and grass. Science 229, 384-386.

Caldwell, M.M., Dawson, T.E., Richards, J.H., 1998. Hydraulic lift: consequences of water efflux from the roots of plants. Oecologia 113, 151-161.

Carlson, R.M., 1978. Automated separation and conductimetric determination of ammonia and dissolved carbon-dioxide. Analytical Chemistry 50, 1528-1531.

Charley, J.L., West, N.E., 1975. Plant-induced soil chemical patterns in some shrubdominated semi-desert ecosystems of Utah. Journal of Ecology 63, 945-963.

Chen, J., Stark, J.M., 2000. Plant species effects and carbon and nitrogen cycling in a sagebrush-crested wheatgrass soil. Soil Biology \& Biochemistry 32, 47-57.

Collins, H.P., Cavigelli, M.A., 2003. Soil microbial community characteristics along an elevation gradient in the Laguna Mountains of southern California. Soil Biology \& Biochemistry 35, 1027-1037.

Cordova-Kreylos, A.L., Cao, Y.P., Green, P.G., Hwang, H.M., Kuivila, K.M., LaMontagne, M.G., Van De Werfhorst, L.C., Holden, P.A., Scow, K.M., 2006. Diversity, composition, and geographical distribution of microbial communities in California salt marsh sediments. Applied and Environmental Microbiology 72, 3357-3366.

Donovan, L.A., Richards, J.H., 2000. Juvenile shrubs show differences in stress tolerance, but no competition or facilitation, along a stress gradient. Journal of Ecology 88, 1-16.

Donovan, L.A., Richards, J.H., Muller, M.W., 1996. Water relations and leaf chemistry of Chrysothamnus nauseosus ssp consimilis (Asteraceae) and Sarcobatus vermiculatus (Chenopodiaceae). American Journal of Botany 83, 1637-1646.

Donovan, L.A., Richards, J.H., Schaber, E.J., 1997. Nutrient relations of the halophytic shrub, Sarcobatus vermiculatus, along a soil salinity gradient. Plant and Soil 190, 105-117.

Dregne, H.E., 1991. Global status of desertification. Annals of Arid Zone 30, 179-185.

Drenovsky, R.E., Richards, J.H., 2005. Nitrogen addition increases fecundity in the desert shrub Sarcobatus vermiculatus. Oecologia 143, 349-356.

Drenovsky, R.E., Richards, J.H., 2006. Low leaf N and P resorption contributes to nutrient limitation in two desert shrubs. Plant Ecology 183, 305-314.

Eshel, G., Levy, G.J., Mingelgrin, U., Singer, M.J., 2004. Critical evaluation of the use of laser diffraction for particle-size distribution analysis. Soil Science Society of America Journal 68, 736-743.
Ewing, S.A., Southard, R.J., Macalady, J.L., Hartshorn, A.S., Johnson, M.J., 2007. Soil microbial fingerprints, carbon and nitrogen in a Mojave Desert creosote-bush ecosystem. Soil Science Society of America Journal 71, 469-475.

Fierer, N., Schimel, J.P., Holden, P.A., 2003a. Influence of drying-rewetting frequency on soil bacterial community structure. Microbial Ecology 45, 63-71.

Fierer, N., Schimel, J.P., Holden, P.A., 2003b. Variations in microbial community composition through two soil depth profiles. Soil Biology \& Biochemistry 35, $167-176$.

Fort, K.P., Richards, J.H., 1998. Does seed dispersal limit initiation of primary succession in desert playas? American Journal of Botany 85, 1722-1731.

Gallardo, A., Schlesinger, W.H., 1992. Carbon and nitrogen limitations of soil microbial biomass in desert ecosystems. Biogeochemistry 18, 1-17.

Gillespie, I.G., Loik, M.E., 2004. Pulse events in Great Basin Desert shrublands: physiological responses of Artemisia tridentata and Purshia tridentata seedlings to increased summer precipitation. Journal of Arid Environments 59, 41-57.

Griffiths, B.S., Ritz, K., Ebblewhite, N., Dobson, G., 1999. Soil microbial community structure: effects of substrate loading rates. Soil Biology \& Biochemistry 31 145-153.

Harris, D., Horwath, W.R., van Kessel, C., 2001. Acid fumigation of soils to remove carbonates prior to total organic carbon or carbon-13 isotopic analysis. Soil Science Society of America Journal 65, 1853-1856.

Hurst, C.J., Knudsen, G.R., McInerney, M.J., Stetzenbach, L.D., Walter, M.V., 1997 Manual of Environmental Microbiology. ASM Press, Washington D.C.

Kaur, A., Chaudhary, A., Kaur, A., Choudhary, R., Kaushik, R., 2005. Phospholipid fatty acid-a bioindicator of environment monitoring and assessment in soil ecosystem. Current Science 89, 1103-1112.

Kourtev, P.S., Ehrenfeld, J.G., Haggblom, M., 2003. Experimental analysis of the effect of exotic and native plant species on the structure and function of soil microbia communities. Soil Biology \& Biochemistry 35, 895-905.

Pankhurst, C.E., Yu, S., Hawke, B.G., Harch, B.D., 2001. Capacity of fatty acid profiles and substrate utilization patterns to describe differences in soil microbial communities associated with increased salinity or alkalinity at three locations in south Australia. Biology and Fertility of Soils 33, 204-217.

Pathak, H., Rao, D.L.N., 1998. Carbon and nitrogen mineralization from added organic matter in saline and alkali soils. Soil Biology \& Biochemistry 30, 695-702.

Pendleton, R.L., Smith, B.N., 1983. Vesicular-arbuscular mycorrhizae of weedy and colonizer plant-species at disturbed sites in Utah. Oecologia 59, 296-301.

Reynolds, J.F., Virginia, R.A., Kemp, P.R., de Soyza, A.G., Tremmel, D.C., 1999. Impact of drought on desert shrubs: effects of seasonality and degree of resource island development. Ecological Monographs 69, 69-106.

Richards, J.H., Caldwell, M.M., 1987. Hydraulic lift-substantial nocturnal water transport between soil layers by Artemisia tridentata roots. Oecologia 73 486-489.

SAS, 2001. SAS/STAT User's Guide. Version 8. SAS Institute, Cary, NC

Schaeffer, S.M., Evans, R.D., 2005. Pulse additions of soil carbon and nitrogen affect soil nitrogen dynamics in an arid Colorado Plateau shrubland. Oecologia 145 425-433.

Schaeffer, S.M., Billings, S.A., Evans, R.D., 2003. Responses of soil nitrogen dynamics in a Mojave desert ecosystem to manipulations in soil carbon and nitrogen availability. Oecologia 134, 547-553.

Schlesinger, W.H., Pilmanis, A.M., 1998. Plant-soil interactions in deserts Biogeochemistry 42, 169-187.

Schlesinger, W.H., Raikes, J.A., Hartley, A.E., Cross, A.F., 1996. On the spatial pattern of soil nutrients in desert ecosystems. Ecology 77 1270-1270.

Sessitsch, A., Weilharter, A., Gerzabek, M.H., Kirchmann, H., Kandeler, E., 2001 Microbial population structures in soil particle size fractions of a long-term fertilizer field experiment. Applied and Environmental Microbiology 67, 4215-4224.

Steenwerth, K.L., Jackson, L.E., Calderon, F.J., Stromberg, M.R., Scow, K.M., 2002. Soil microbial community composition and land use history in cultivated and grassland ecosystems of coastal California. Soil Biology \& Biochemistry 34, 1599-1611.

Stine, S., 1990. Late Holocene fluctuations of Mono Lake, eastern California Palaeogeography, Palaeoclimatology. Palaeoecology 78, 333-381.

Sylvia, D.M., Fuhrmann, J.J., Hartel, P.G., Zubere, D.A., 1998. Principles and Applications of Soil Microbiology. Prentice Hall, Princeton.

terBraak, C.J., Šmilauer, L., 1998. CANOCO Reference Manual and User's Guide to CANOCO for Windows. Microcomputer Power, Ithaca, NY.

Toft, C., Elliott-Fisk, D., 2002. Patterns of vegetation along a spatiotemporal gradient on shoreline strands of a desert basin lake. Plant Ecology 158, 21-39.

Vasek, F.C., Lund, L.J., 1980. Soil characteristics associated with a primary plant succession on a Mojave Desert dry lake. Ecology 61, 1013-1018.

Vollmer, A.T., Au, F., Bamberg, S.A., 1977. Observations on the distribution of microorganisms in desert soils. Great Basin Naturalist 37, 81-86.

White, D.C., Stair, J.O., Ringelberg, D.B., 1996. Quantitative comparisons of in situ microbial biodiversity by signature biomarker analysis. Journal of Industrial Microbiology 17, 185-196.

Wilkinson, S.C., Anderson, J.M., Scardelis, S.P., Tisiafouli, M., Taylor, A., Wolters, V. 2002. PLFA profiles of microbial communities in decomposing conifer litters subject to moisture stress. Soil Biology \& Biochemistry 34, 189-200.

Zelles, L., Bai, Q.Y., Ma, R.X., Rackwitz, R., Winter, K., Beese, F., 1994. Microbial biomass, metabolic-activity and nutritional-status determined from fatty-acid patterns and poly-hydroxybutyrate in agriculturally-managed soils. Soil Biology \& Biochemistry 26, 439-446. 